\title{
Knowledge and Practices of Mothers towards Infant Oral Health Care in Their Children's First Year of Life
}

\section{Conhecimentos e Práticas de Mães Sobre a Saúde Bucal Infantil no Primeiro Ano de Vida de seus Filhos}

\author{
Mayara Delfino Sentone Rossato ; Márjori Frítola*b; Paulo Henrique Rossato ${ }^{\mathrm{c}}$; Valéria Campos Mariano Francelino ${ }^{\mathrm{b}}$; \\ Regina Célia Poli-Frederico ${ }^{a}$; Alexandrina Aparecida Maciel Cardellid; Sandra Mara Maciel ${ }^{b}$
}

\author{
${ }^{a}$ Unopar, Stricto Sensu Post-Graduate Program in Dentistry. PR, Brasil. \\ bUniversidade Estadual de Maringá, Post-Graduate Program in Integrated Dentistry. PR, Brasil. \\ 'Instituto Federal do Paraná. PR, Brasil. \\ ${ }^{d}$ Universidade Estadual de Londrina, Post-Graduate Program in Nursing. PR, Brasil. \\ *E-mail: mfritola@gmail.com
}

\begin{abstract}
This study aimed to assess mothers' oral health-related knowledge and practices in immediate and late puerperium, and in the child's first year of life. This study is a prospective cohort study, in which data were collected from 358 mothers of children born between 2013 and 2014 , in immediate and late puerperium, and in children's first year of life, by interviews with sociodemographic characterization and oral health questionnaires, and were analyzed by descriptive statistics and Chi-square test $(\alpha=5 \%)$. Participants were mainly aged 20 to 29 years $(53.9 \%)$, with 7 to 11 years of education $(67.6 \%)$, from low social class $(72.3 \%)$, unemployed $(58.9 \%)$, married or in common-law marriage $(84.1 \%)$, with more than one child $(60.1 \%)$. Although $51.7 \%$ of them had received information about children's oral health, only $0.8 \%, 32.4 \%$ and $13.7 \%$, respectively, knew the concept, etiology and preventive attitudes regarding dental caries. Mothers aged under 20 and over 30 years, with lower education and from low social class presented significantly lower oral health-related knowledge. At children's first year of life, although $78.7 \%$ of the children had already been taken to the dentist, half of them had already tasted sugary foods and drinks. It is highlighted the social determination and the need of an improvement of mothers' oral health-related knowledge and practices. Educational actions, especially in prenatal programs, are important to achieve this improvement and to decrease early childhood caries rates.
\end{abstract}

Keywords: Dental Caries. Child. Health Knowledge Attitudes, Practice. Parents. Oral Health.

\section{Resumo}

Avaliar o conhecimento e as práticas de mães sobre a saúde bucal de seus filhos no puerpério imediato, tardio, e no primeiro ano de vida da criança. Trata-se de um estudo de coorte prospectiva, no qual os dados foram coletados de 358 mães de bebês nascidos entre 2013 e 2014 , no puerpério imediato, tardio e um ano após o parto, por entrevistas com perguntas sobre dados sociodemográficos e sobre saúde bucal. Os dados foram analisados por estatísticas descritivas e pelo teste Qui-quadrado $(\alpha=5 \%)$. As participantes apresentavam, majoritariamente, idades entre 20 a 29 anos (53,9\%), com 7 a 11 anos de estudo (67,6\%), eram de baixa classe social (72,3\%), desempregadas (58,9\%), casadas ou em união estável (84,1\%), e tinham mais de um filho (60,1\%). Apesar de 51.7\% delas afirmarem ter recebido informações sobre saúde bucal infantil, apenas $0,8 \%, 32,4 \%$ e 13,7\%, respectivamente, sabiam o conceito, etiologia e as atitudes preventivas à cárie. Mães com idades abaixo de 20 e acima de 29 anos apresentaram menor conhecimento sobre saúde bucal do que as demais. No primeiro ano de vida, apesar de $78,7 \%$ das crianças já terem ido ao dentista, metade delas já havia experimentado alimentos e bebidas açucarados. Destaca-se a determinação social e a necessidade de melhora no conhecimento e práticas das mães sobre saúde bucal. Ações educativas, especialmente em programas de atenção pré-natal, são importantes para atingir essa melhora e, consequentemente, diminuir as taxas da cárie na primeira infância.

Palavras-chave: Cárie Dentária. Criança. Conhecimentos, Atitudes e Práticas em Saúde. Pais. Saúde Bucal.

\section{Introduction}

Mothers' knowledge and practices towards oral health may be determinant to the occurrence of early childhood caries in their children. This disease reaches prevalence between 20 and $74 \%$ in children under six years old, ${ }^{1-5}$ and its occurrence can negatively impact the oral and systemic health by reducing the masticatory performance and impairing the nutritional status, for example. ${ }^{3,6}$ Among other factors, such prevalence may be explained by the mothers' lack of knowledge regarding the children's oral health care, as poor oral health-related knowledge (OHK) and practices (OHP) of mothers regarding their children are related to higher indexes of early childhood caries. $^{7-9}$ In this context, findings from studies that assess mothers' OHK and OHP regarding their children can provide grounds to the implementation of strategies of prevention and promotion of children's oral health.9-11

Some studies had already assessed mothers' OHK and OHP. And in these studies, for example, as mothers did not present awareness of the need to start toothbrushing since the eruption of the baby's first teeth, their knowledge and practices were likely to need an improvement. ${ }^{10,12}$ Remarkably, oral healthrelated practices are acquired from parents, and therefore, they play a determining role in the children's oral health; and that is the main reason why mothers should present higher levels of OHK and adequate OHP, to guarantee their children a good oral health. . $^{8,911-13}$

OHK levels can be influenced by factors such as age, 
educational status, mother's employment status and household income, being younger mothers, with lower education, unemployed and from lower income families those who present lower levels of OHK. ${ }^{9,12}$ Faced with mothers' poor $\mathrm{OHK}$ and OHP, it is highlighted the necessity of educational strategies towards the children's oral health care. And those strategies should be especially focused on mothers of children aged 0 to 6 years, mainly those who are younger, with lower education, unemployed and from lower income families, with the aim to reduce the occurrence of oral chronic diseases in pre-school children. ${ }^{2}$ Further, it is suggested that mothers must be made aware of this issue since prenatal and puerperal period, with reinforcement on the information received, in every new child's dental appointment. ${ }^{7,10}$

The majority of studies that assess OHK and OHP were conducted with mothers whose children were already above 12 months of age. ${ }^{10,11}$ As children of such age would have at least one erupted tooth, probably, the parents would have already started the routines regarding oral hygiene towards them; therefore, they must have had correct information about this issue, to perform such routines in an adequate way. Or, on the contrary, if the parents were not aware of the need to start toothbrushing as the child's first tooth erupts, children around 12 months age and above would be lacking their adequate oral healthcare. Furthermore, the first year of age is highlighted as a determining moment of children's development, and it offers a window of opportunities to the establishment of healthy habits regarding oral and systemic health. ${ }^{14-16}$ Consequently, it would be ideal that the assessment of mothers' OHK and OHP would be carried out before their children's first year of life. Hence, this study aimed to assess oral health-related knowledge and practices of mothers regarding their children, in immediate and late puerperal periods, and in children's first year of life.

\section{Material and Methods}

The present study is part of the prospective cohort "Risk factors for maternal and child morbidity and mortality: from gestational period to the first year post-delivery ", which aimed to assess health care targeted to women in the prenatal period, in the delivery and puerperal period, and to the child in the first year of life, in Londrina, Brazil. This study was approved by the Ethics Committee from the State University of Londrina (approval number 19352513.9.0000.5231), and abided by the Declaration of Helsinki. A signed Informed Consent Form was required from each participant to compose the sample.

The sample was composed of mothers of children born in 2013 and 2014 at Lucilla Ballalai Municipal Maternity Hospital (LBMMH), and it was calculated considering 5\% as the margin of error, $95 \%$ as a confidence interval, and the 3,415 childbirths that occurred in LBMMH in 2012, and thus, it was set at 358 participants. The inclusion criterion was to be one of the patients during the hospital stay in LBMMH in the puerperal period and, therefore: to be registered in one of the Basic Health Care Unities (BHU) of the $17^{\text {th }}$ Healthcare Regional and have the diagnostic of pregnancy of low or moderate risk before the delivery (gestational age above 37 weeks and no systemic illnesses associated). The data collection was performed in three stages, by students from the Post-Graduate Program in Nursing, previously trained for the collection of oral health data. The first stage was conducted during the hospital stay, in the immediate puerperal period. Daily interviews were carried out until the proposed sample number was reached. The data collection consisted of the participant's identification and the fulfillment of a structured questionnaire with personal, sociodemographic, and obstetric data, obtained from interviews, from their medical records.

The second stage was conducted during a pre-scheduled home visit in the mother's late puerperal period (until 42 days after childbirth). Data regarding previous information received by mothers concerning the children's oral health, knowledge about dental caries and primary teeth, use of pacifiers, dietary practices, and OHP targeted to the baby were registered in a semi-structured questionnaire.

The third stage was conducted one year after the childbirth, also in a pre-scheduled home visit. The data collected in this stage were about primary health care, seek for health care, and child's oral health. These data were obtained through an interview and registered in a semi-structured questionnaire.

The statistical analysis was performed in the software Statistical Package for Social Sciences (SPSS) 20.0 version. Data were analyzed by descriptive statistics and by Chi-square test, with $5 \%$ of significance $(p<0.05)$.

\section{Results and Discussion}

The final sample in the third stage of this study was composed of 310 mothers and, therefore, the sample loss was $13.4 \%$, which occurred due to wrong home addresses, change of phone numbers, and the decision to quit the study. The mothers' sociodemographic characteristics of the sample are described in Figure 1.

Figure 1 - Mothers' sociodemographic characteristics of the sample
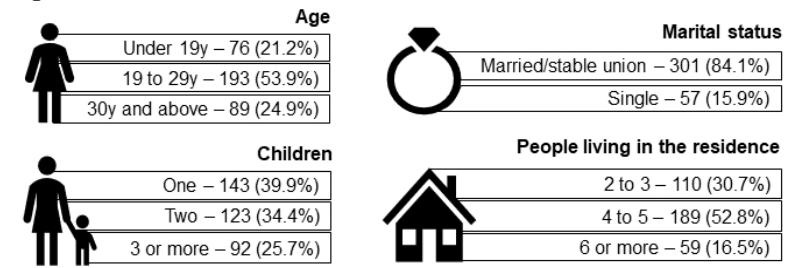

Formal education
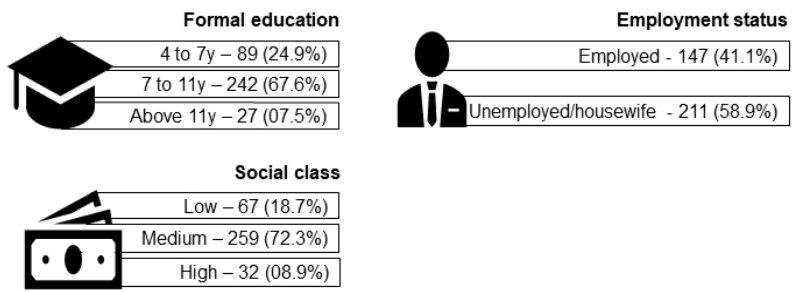

Source: The authors. 
During the prenatal period, the majority of mothers $(86 \%)$ went to six or more medical appointments, while $12.6 \%$ and $1.4 \%$ went from three to five and zero to two medical appointments, respectively. On the other way round, only $62.3 \%$ of the mothers went to at least one dental appointment during pregnancy. The reasons to seek dental care at the BHU were: prenatal dental care $(52.4 \%)$, urgency care $(8.1 \%)$, restorative treatment $(8.1 \%)$, and $31.4 \%$ of them did not answer. The reasons to explain the failure to seek dental care at the BHU were: the lack of vacancies at the BHU (23.7\%), laziness/fear/lack of time (45.9\%), attending private practice $(5.9 \%)$ and $24.5 \%$ of them did not answer. Regarding puerperal period, only $47.2 \%$ of the mothers sought for dental care at the BHU.

Information concerning mothers' OHK in the second stage of the study (late puerperal period) is expressed in table 1.

Table 1 - Mothers' knowledge about the children's oral health in the second stage of the study $(\mathrm{n}=358)$

\begin{tabular}{|c|c|c|c|}
\hline \multicolumn{2}{|r|}{ Questions } & $N$ & $\%$ \\
\hline \multirow{5}{*}{$\begin{array}{l}\text { At what age } \\
\text { can children } \\
\text { perform } \\
\text { toothbrushing } \\
\text { by themselves? }\end{array}$} & Zero to two years & 104 & 29.1 \\
\hline & Three to five years & 150 & 41.9 \\
\hline & Six to eight years & 66 & 18.4 \\
\hline & Above eight years & 27 & 7.5 \\
\hline & Do not know & 11 & 3.1 \\
\hline \multirow{5}{*}{$\begin{array}{l}\text { What is dental } \\
\text { caries? }\end{array}$} & A disease & 2 & 0.8 \\
\hline & A bacterium & 97 & 36.9 \\
\hline & A plaque & 53 & 20.2 \\
\hline & A stain or a black spot & 76 & 28.9 \\
\hline & $\begin{array}{l}\text { Something that damages the } \\
\text { tooth }\end{array}$ & 35 & 13.3 \\
\hline \multirow{3}{*}{$\begin{array}{l}\text { What is the } \\
\text { cause of tooth } \\
\text { caries? }\end{array}$} & Lack of oral hygiene & 183 & 51.1 \\
\hline & $\begin{array}{l}\text { High frequency of sugar } \\
\text { consumption }\end{array}$ & 59 & 16.5 \\
\hline & Both factors & 116 & 32.4 \\
\hline \multirow{4}{*}{$\begin{array}{l}\text { How can the } \\
\text { occurrence of } \\
\text { dental caries be } \\
\text { prevented? }\end{array}$} & By regular oral hygiene & 259 & 75.3 \\
\hline & $\begin{array}{l}\text { By regular oral hygiene and } \\
\text { dental care }\end{array}$ & 25 & 7.3 \\
\hline & $\begin{array}{l}\text { By avoiding frequent sugar } \\
\text { consumption }\end{array}$ & 13 & 3.8 \\
\hline & $\begin{array}{l}\text { By regular oral hygiene and } \\
\text { avoiding frequent sugar } \\
\text { consumption }\end{array}$ & 47 & 13.7 \\
\hline \multirow{2}{*}{$\begin{array}{l}\text { Do you know } \\
\text { when the first } \\
\text { primary teeth } \\
\text { eruption occurs? }\end{array}$} & Yes & 246 & 68.7 \\
\hline & No & 112 & 31.3 \\
\hline \multirow{4}{*}{$\begin{array}{l}\text { If affirmative, } \\
\text { when does } \\
\text { it occur and } \\
\text { what is the first } \\
\text { tooth to erupt? } \\
(\mathrm{n}=246)\end{array}$} & $\begin{array}{l}\text { From } 4 \text { to } 6 \text { months of age, } \\
\text { lower incisors }\end{array}$ & 198 & 80.5 \\
\hline & $\begin{array}{l}\text { From } 7 \text { to } 10 \text { months of age, } \\
\text { lower incisors }\end{array}$ & 34 & 13.8 \\
\hline & $\begin{array}{l}\text { At } 12 \text { months of age, lower } \\
\text { incisors }\end{array}$ & 11 & 4.5 \\
\hline & $\begin{array}{l}\text { At } 6 \text { months of age, any other } \\
\text { tooth }\end{array}$ & 3 & 1.2 \\
\hline \multirow{4}{*}{$\begin{array}{l}\text { At what age } \\
\text { should baby's } \\
\text { first dental } \\
\text { appointment } \\
\text { occur? }\end{array}$} & $\begin{array}{l}\text { As soon as possible, after } \\
\text { childbirth }\end{array}$ & 102 & 28.5 \\
\hline & $\begin{array}{l}\text { When the first tooth eruption } \\
\text { occurs }\end{array}$ & 114 & 31.8 \\
\hline & $\begin{array}{l}\text { During the child's first year of } \\
\text { life }\end{array}$ & 124 & 34.6 \\
\hline & After the child's first year of life & 18 & 5.1 \\
\hline
\end{tabular}

Associations between mothers' OHK and sociodemographic variables are expressed in Table 2.

Table 2 - Association between mothers' ages, social class and education status and their knowledge regarding children's oral health (second stage) $(\mathrm{n}=358)$

\begin{tabular}{|c|c|c|c|}
\hline \multicolumn{4}{|c|}{ Questions } \\
\hline \multicolumn{4}{|c|}{ Do you know what dental caries is? } \\
\hline & \multicolumn{3}{|c|}{ Age - N (\%) } \\
\hline & $\leq 19 \mathrm{y}$ & $20-29 y$ & $\geq 30 \mathrm{y}$ \\
\hline Yes & $44(57.9)$ & $154 *(79.8)$ & $6(54.5)$ \\
\hline \multirow[t]{3}{*}{ No } & $32(42.1)$ & $39(20.2)$ & $5(45.5)$ \\
\hline & \multicolumn{3}{|c|}{ Social class - N $(\%)$} \\
\hline & High & Medium & Low \\
\hline Yes & $52(77.6)$ & $190(73.4)$ & $22(68.8)$ \\
\hline \multirow[t]{3}{*}{ No } & $15(22.4)$ & $69(26.6)$ & $10(31.3)$ \\
\hline & \multicolumn{3}{|c|}{ Education - N (\%) } \\
\hline & 4 to $7 \mathrm{y}$ & 7 a 11 y & $>11 \mathrm{y}$ \\
\hline Yes & $61(68.5)$ & $180(74.4)$ & $23(85.2)$ \\
\hline No & $28(31.5)$ & $62(25.6)$ & $4(14.8)$ \\
\hline \multicolumn{4}{|c|}{ What are the causes of the dental caries? } \\
\hline & \multicolumn{3}{|c|}{ Age - N (\%) } \\
\hline & $\leq 19 \mathrm{y}$ & $20-29 \mathrm{y}$ & $\geq 30 \mathrm{y}$ \\
\hline Poor oral hygiene & $42(55.3)$ & $93(48.2)$ & $7(63.6)$ \\
\hline $\begin{array}{l}\text { Consumption } \\
\text { of sugar in high } \\
\text { frequencies }\end{array}$ & $18(23.6)$ & $28(14.5)$ & $2(18.2)$ \\
\hline \multirow[t]{3}{*}{ Both practices } & $16(21.1)$ & $72(37.3)$ & $2(18.2)$ \\
\hline & \multicolumn{3}{|c|}{ Social class - N $(\%)$} \\
\hline & High & Medium & Low \\
\hline Poor oral hygiene & $37(55.2)$ & $134(51.7)$ & $12(37.5)$ \\
\hline $\begin{array}{c}\text { Consumption } \\
\text { of sugar in high } \\
\text { frequencies }\end{array}$ & $9(13.5)$ & $42(16.2)$ & $8(25.0)$ \\
\hline \multirow[t]{3}{*}{ Both practices } & $21(31.3)$ & $83(32.1)$ & $12(37.5)$ \\
\hline & \multicolumn{3}{|c|}{ Education - N (\%) } \\
\hline & 4 to $7 \mathrm{y}$ & 7 a 11 y & $>11 \mathrm{y}$ \\
\hline Poor oral hygiene & $47(50.8)$ & $123(50.8)$ & $13(48.1)$ \\
\hline $\begin{array}{c}\text { Consumption } \\
\text { of sugar in high } \\
\text { frequencies }\end{array}$ & $21(23.6)$ & $34(14.1)$ & $4(14.8)$ \\
\hline Both practices & $21(23.6)$ & $85(35.1)$ & $10(37.1)$ \\
\hline
\end{tabular}

Do you know at what age the eruption of the first primary tooth occurs

\begin{tabular}{|r|c|c|c|}
\hline \multirow{2}{*}{} & \multicolumn{3}{|c|}{ Age - N (\%) } \\
\cline { 2 - 4 } & $\leq 19 \mathrm{y}$ & $20-29 \mathrm{y}$ & $\geq 30 \mathrm{y}$ \\
\hline Yes & $49(64.5)$ & $134(69.4)$ & $6(54.5)$ \\
\hline No & $27(35.5)$ & $59(30.6)$ & $5(45.5)$ \\
\hline & \multicolumn{3}{|c|}{ Social class - N (\%) } \\
\cline { 2 - 4 } & High & Medium & Low \\
\hline Yes & $52(77.6)$ & $180(69.5)$ & $14^{*}(43.8)$ \\
\hline No & $15(22.4)$ & $79(30.5)$ & $18(56.3)$ \\
\hline & \multicolumn{3}{|c|}{ Education - N (\%) } \\
\cline { 2 - 4 } & 4 to 7 y & 7 a 11 y & $>11$ y \\
\hline Yes & $56(62.9)$ & $171(70.7)$ & $19(70.4)$ \\
\hline No & $33(37.1)$ & $71(29.3)$ & $8(29.6)$ \\
\hline
\end{tabular}

At what age can children perform toothbrushing by themselves?

\begin{tabular}{|r|c|c|c|}
\hline \multirow{2}{*}{} & \multicolumn{3}{|c|}{ Age - N (\%) } \\
\cline { 2 - 4 } & $\leq 19 \mathrm{y}$ & $20-29 \mathrm{y}$ & $\geq 30 \mathrm{y}$ \\
\hline 0 to 2 years & $28(36.8)$ & $48(24.9)$ & $6(54.5)$ \\
\hline 3 to 5 years & $36(47.4)$ & $82(42.5)$ & $2(18.2)$ \\
\hline 6 years or above & $12(15.8)$ & $\mathbf{6 3}$ * (32.6) & $3(27.3)$ \\
\hline & \multicolumn{3}{|c|}{ Social class - N (\%) } \\
\cline { 2 - 4 } & High & \multicolumn{3}{|c|}{ Medium } & Low \\
\hline
\end{tabular}




\begin{tabular}{|c|c|c|c|}
\hline 0 to 2 years & $14(20.9)$ & $74(28.6)$ & $16(50.0)$ \\
\hline 3 to 5 years & $29(43.3)$ & $108(41.7)$ & $13(40.6)$ \\
\hline \multirow[t]{3}{*}{6 years or above } & $24(35.8)$ & $77(29.7)$ & $3 *(9.4)$ \\
\hline & \multicolumn{3}{|c|}{ Education - N (\%) } \\
\hline & 4 to $7 \mathrm{y}$ & 7 a 11 y & $>11 \mathrm{y}$ \\
\hline 0 to 2 years & $29(32.6)$ & $68(28.1)$ & $7(25.9)$ \\
\hline 3 to 5 years & $37(41.6)$ & $108(44.6)$ & $5(18.5)$ \\
\hline 6 years or above & $23(25.8)$ & $66(27.3)$ & $15 *(55.6)$ \\
\hline \multicolumn{4}{|c|}{ Do you know what the advantages of breastfeeding are? } \\
\hline & \multicolumn{3}{|c|}{ Age - N (\%) } \\
\hline & $\leq 19 \mathrm{y}$ & $20-29 \mathrm{y}$ & $\geq 30 \mathrm{y}$ \\
\hline Yes & $58(76.3)$ & $177 *(91.7)$ & $9(81.8)$ \\
\hline \multirow[t]{3}{*}{ No } & $18(23.7)$ & $16(8.3)$ & $2(18.2)$ \\
\hline & \multicolumn{3}{|c|}{ Social class $-\mathbf{N}(\%)$} \\
\hline & High & Medium & Low \\
\hline Yes & $66 *(98.5)$ & $222(85.7)$ & $26(81.3)$ \\
\hline \multirow[t]{3}{*}{ No } & $1(1.5)$ & $37(14.3)$ & $6(18.8)$ \\
\hline & \multicolumn{3}{|c|}{ Education - N (\%) } \\
\hline & 4 to $7 \mathrm{y}$ & 7 a 11 y & $>11 \mathrm{y}$ \\
\hline Yes & $73(82.0)$ & $214(88.4)$ & $27 *(100)$ \\
\hline No & $16(18.0)$ & $28(11.6)$ & $0(0)$ \\
\hline
\end{tabular}

Source: Resource data.

Mothers from 20 to 29 years achieved more correct answers in the question "At what age can children brush their teeth by themselves?" ( $p=0.01$ ), and higher percentages of them knew what dental caries is $(\mathrm{p}=0.01)$ and what the advantages of breastfeeding are $(\mathrm{p}=0.01)$. Mothers with higher education achieved more correct answers in the question "At what age can children perform toothbrushing by themselves?" ( $p=0.03$ ) and higher percentages of them knew about the advantages of breastfeeding $(\mathrm{p}=0.02)$. Higher amounts of mothers from high social class knew when the eruption of the first primary teeth occurs $(p=0.02)$, and the advantages of breastfeeding $(p=0.04)$. Mothers from higher social classes also achieved more correct answers in the question "At what age can children perform toothbrushing by themselves?" $(p=0.02)$.

Mothers' OHP in the second stage of the study (late puerperal period) and in the third stage of the study (children's first year of life) are respectively expressed in Table 3 and table 4.

Table 3 - Mothers' practices towards baby's diet, oral care and sucking habits in the second stage of the study $(n=358)$

\begin{tabular}{|c|c|c|c|}
\hline \multicolumn{2}{|c|}{ Questions } & \multirow{2}{*}{$\begin{array}{c}N \\
145\end{array}$} & \multirow{2}{*}{$\begin{array}{c}\% \\
40.5\end{array}$} \\
\hline $\begin{array}{l}\text { Do you have } \\
\text { the habit to }\end{array}$ & Yes & & \\
\hline $\begin{array}{l}\text { baby to soothe } \\
\text { him/her? }\end{array}$ & No & 213 & 59.5 \\
\hline \multirow{2}{*}{$\begin{array}{l}\text { If affirmative, } \\
\text { do you add } \\
\text { sugar in the tea } \\
\text { to offer to your } \\
\text { baby? }(n=145)\end{array}$} & Yes & 54 & 37.2 \\
\hline & No & 91 & 62.8 \\
\hline \multirow{4}{*}{$\begin{array}{l}\text { What is the } \\
\text { type of your } \\
\text { baby's feeding? }\end{array}$} & Exclusive breastfeeding & 166 & 46.4 \\
\hline & Breastfeeding, tea and water & 56 & 15.6 \\
\hline & Breastfeeding and bottle feeding & 99 & 27.7 \\
\hline & Bottle feeding & 37 & 10.3 \\
\hline
\end{tabular}

\begin{tabular}{|c|c|c|c|}
\hline \multirow{2}{*}{$\begin{array}{l}\text { Does your baby } \\
\text { have the habit } \\
\text { to fall asleep } \\
\text { while drinking } \\
\text { from a bottle? } \\
(\mathrm{n}=136)\end{array}$} & Yes & 50 & 36.8 \\
\hline & No & 86 & 63.2 \\
\hline \multirow{2}{*}{$\begin{array}{l}\text { What is the } \\
\text { content of the } \\
\text { bottle that you } \\
\text { offer to your } \\
\text { baby? }(\mathrm{n}=136)\end{array}$} & Only milk & 103 & 73.0 \\
\hline & $\begin{array}{l}\text { Milk with an added sweet } \\
\text { content }\end{array}$ & 33 & 27.0 \\
\hline \multirow{2}{*}{$\begin{array}{l}\text { Does your baby } \\
\text { use pacifier? }\end{array}$} & Yes & 157 & 43.9 \\
\hline & \begin{tabular}{|l|} 
No \\
\end{tabular} & 201 & 56.1 \\
\hline \multirow{5}{*}{$\begin{array}{l}\text { Why does } \\
\text { your baby use } \\
\text { the pacifier? } \\
(\mathrm{n}=157)\end{array}$} & Crying & 23 & 14.6 \\
\hline & Colic & 7 & 4.5 \\
\hline & To calm down & 67 & 42.7 \\
\hline & To fall asleep & 57 & 36.3 \\
\hline & To avoid finger sucking & 3 & 1.9 \\
\hline \multirow{2}{*}{$\begin{array}{l}\text { Did you } \\
\text { already start } \\
\text { your baby's } \\
\text { oral hygiene? }\end{array}$} & Yes & 302 & 84.4 \\
\hline & No & 56 & 15.6 \\
\hline \multirow{2}{*}{$\begin{array}{l}\text { If affirmative, } \\
\text { how do you } \\
\text { carry out } \\
\text { your baby's } \\
\text { oral hygiene? } \\
(\mathrm{n}=302)\end{array}$} & $\begin{array}{l}\text { Gauze/cloth moistened with tap } \\
\text { water }\end{array}$ & 253 & 83.3 \\
\hline & $\begin{array}{l}\text { Gauze/cloth moistened with } \\
\text { boiled or mineral water or } \\
\text { physiological saline }\end{array}$ & 49 & 16.2 \\
\hline \multirow{5}{*}{$\begin{array}{l}\text { What is the } \\
\text { frequency in } \\
\text { which you } \\
\text { perform your } \\
\text { baby's oral } \\
\text { hygiene? }\end{array}$} & Once a day & 105 & 34.9 \\
\hline & Twice a day & 100 & 33.2 \\
\hline & Three times a day & 36 & 12.0 \\
\hline & More than three times a day & 22 & 7.3 \\
\hline & Alternate days & 38 & 12.6 \\
\hline
\end{tabular}

Source: Resource data.

Table 4 - Mothers' practices regarding their babies' feeding, and the seeking of dental care to their babies, in their first year of life (third stage) $(\mathrm{n}=310)$

\begin{tabular}{|c|c|c|c|}
\hline \multicolumn{2}{|l|}{ Variables } & $N$ & $\%$ \\
\hline \multirow{2}{*}{$\begin{array}{l}\text { Breastfeeding } \\
\text { duration }\end{array}$} & Less than 6 months & 193 & 62.3 \\
\hline & 6 months or more & 117 & 37.7 \\
\hline \multirow{3}{*}{ Type of feeding } & Breastfeeding & 41 & 13.2 \\
\hline & Bottle feeding & 189 & 61.0 \\
\hline & $\begin{array}{l}\text { Breastfeeding and bottle } \\
\text { feeding }\end{array}$ & 80 & 25.8 \\
\hline \multirow{2}{*}{$\begin{array}{l}\text { Do you offer } \\
\text { industrialized } \\
\text { juice to your } \\
\text { baby? }\end{array}$} & Yes & 204 & 65.8 \\
\hline & No & 106 & 34.2 \\
\hline \multirow{2}{*}{$\begin{array}{l}\text { Do you offer } \\
\text { biscuits to your } \\
\text { baby? }\end{array}$} & Yes & 281 & 90.6 \\
\hline & No & 29 & 9.4 \\
\hline \multirow{2}{*}{$\begin{array}{l}\text { Do you offer } \\
\text { soft drinks to } \\
\text { your baby? }\end{array}$} & Yes & 154 & 49.7 \\
\hline & No & 156 & 50.3 \\
\hline \multirow{2}{*}{$\begin{array}{l}\text { Do you offer } \\
\text { sweets to your } \\
\text { baby? }\end{array}$} & Yes & 174 & 56.1 \\
\hline & No & 136 & 43.9 \\
\hline \multirow{2}{*}{$\begin{array}{l}\text { Have you } \\
\text { already sought } \\
\text { for dental care } \\
\text { for your baby } \\
\text { in his/her first } \\
\text { year of life? }\end{array}$} & Yes & 244 & 78.7 \\
\hline & No & 66 & 21.3 \\
\hline
\end{tabular}


Continuation

\begin{tabular}{|c|c|c|c|}
\hline \multirow{2}{*}{$\begin{array}{l}\text { If affirmative, } \\
\text { what is the } \\
\text { reason for } \\
\text { seeking dental } \\
\text { care to him/ } \\
\text { her? }\end{array}$} & $\begin{array}{l}\text { Referred from Maternity or by a } \\
\text { BHU professional }\end{array}$ & 178 & 73.0 \\
\hline & $\begin{array}{l}\text { To receive information about } \\
\text { children's oral health }\end{array}$ & 66 & 27.0 \\
\hline \multirow{2}{*}{$\begin{array}{l}\text { If negative, } \\
\text { what is the } \\
\text { reason for not } \\
\text { to seek dental } \\
\text { care to him/ } \\
\text { her? }\end{array}$} & $\begin{array}{l}\text { Lack of vacancy/Reform or } \\
\text { poor structure of the BHU }\end{array}$ & 26 & 40.6 \\
\hline & Forgot/Laziness/Lack of time & 40 & 59.4 \\
\hline \multirow{4}{*}{$\begin{array}{l}\text { During your } \\
\text { baby's first year } \\
\text { of life, how } \\
\text { many dental } \\
\text { appointments } \\
\text { did you take } \\
\text { him/her to? }\end{array}$} & 1 to 2 & 144 & 46.5 \\
\hline & 3 to 4 & 88 & 28.4 \\
\hline & More than 5 & 12 & 3.9 \\
\hline & $\begin{array}{l}\text { Did not seek for dental care for } \\
\text { the baby }\end{array}$ & 66 & 21.2 \\
\hline
\end{tabular}

Source: Resource data.

This study assessed mothers' OHK and OHP towards infant oral health care in the late puerperal period and one year after childbirth. In other studies ${ }^{10,11}$ these parameters were assessed only near or after the first year of children's life, when early childhood caries could be possibly occurring if inadequate oral health-related habits towards the child had already been established. If mothers' OHK and OHP are poor, there is a need to improve them by the awareness of mothers and the change of OHP. Hence, as the older the children are, the more difficult it is to change OHP that have long been established in the family. Thus, assessing mothers' OHK and OHP since puerperal period or pregnancy is an important strategy, because it may help in the establishment of good OHK and OHP even before tooth eruption. Beyond the contribution to lower ranges of early childhood caries, it may also help to reduce the risk of chronic diseases, as obesity, since they have etiologic factors in common. ${ }^{17}$

Studies that assess mothers' OHK and OHP may provide grounds to the implementation of preventive strategies towards children's oral health. In the second stage of this study, mothers' OHK was shown to be scarce, because more than a half of them answered incorrectly five out of six questions. Those mothers were not aware of: the recommended age for the first dental appointment, the age in which children are able to brush their teeth by themselves, the concept and causes of dental caries and attitudes to prevent its occurrence. Low levels of OHK were found in other studies. . $^{10,12,18}$

In accordance to our findings, in another study the majority of mothers was not aware of the recommended age for the first dental appointment; ${ }^{10}$ and it is a key point that must be taken into account to improve OHK in general population. If the first dental appointment occurs until the 12 months of age, as recommended, the dentist would be able to provide correct parental education about the children's oral health. ${ }^{19}$ The first year of life is a period in which tooth eruption and complementary feeding start simultaneously. And that means a window of infectivity by microbiological etiological agents of caries, and also a window of opportunity to the establishment of a diet based in high frequencies of sugar consumption..$^{20,21}$

Mothers' OHK was associated with sociodemographic parameters, being those mothers aged from 20 to 29 years, from high social class and with higher education who presented higher levels of OHK. These findings corroborate with other studies, in which mothers' ages, ${ }^{2}$ education, ${ }^{12,22}$ household income ${ }^{12}$ and socioeconomic status ${ }^{9}$ were positively related to their OHK. Mothers' education, employment status is reported to be also predictors of the OHP regarding their children. ${ }^{12,22}$ Also, in the second stage of this study, it could be seen that mothers' OHP were poor. Although most of the mothers had already started their babies' oral hygiene, the majority of babies were no longer exclusively breastfed and about one third of them used to fall asleep while drinking from a bottle, being sugar-sweetened milk the content of the bottle. Worryingly, these poor practices are reported to be carried out since late puerperal period (until 42 days after childbirth). The introduction of sugary foods and beverages in infant diet before 6 months of age is positively related to the occurrence of severe early childhood caries. ${ }^{1}$ Also, the duration of breastfeeding for less than 6 months of age is associated with higher risks for early childhood caries. ${ }^{23}$

Although, in the second stage of the study, the majority of mothers were not aware of the recommended age for the first dental appointment, in the third stage, more than two thirds of the babies had already been taken to the dentist within the first year of life. Possibly this could be explained by the referral from the Maternity or a BHU professional for dental care by the Brazilian Universal Healthcare System (SUS). Children whose mothers received prenatal care at a BHU with the implementation of Family Health Strategy are more likely to receive professional dental care since preschool age, ${ }^{24}$ what certainly must impact positively their oral health. In addition, Londrina is a city that takes part of the "Programa Rede Mãe Paranaense", a public healthcare strategy targeted to pregnant women, which aims to reduce maternal and child mortality rates and promote health-related quality of life to pregnant women and their infants.$^{25}$ Mothers enrolled in the program are entitled to prenatal dental appointments, and also guaranteed dental care for their babies.

Controversially, regarding OHP, a significant part of the babies had already been introduced to sugary foods and beverages. The exposure to these foods and beverages during the first year of life is associated to the occurrence of early childhood caries. ${ }^{1}$ Regarding breastfeeding, only $37.7 \%$ of the mothers maintained it after 6 months of age and only $13.2 \%$ were still maintaining it. Although breastfeeding beyond 12 months of age is reported to be related to increased risks of early childhood caries, this association may occur due to other factors that are linked to prolonged breastfeeding, such as nocturnal feeding and poor oral hygiene practices. ${ }^{23}$ Inadequate mothers' OHP towards their children were also 
reported in other studies.$^{10}$

Due the fact that the majority of children in this study were already taken to the dentist, it was expected that mothers' $\mathrm{OHK}$ and OHP were good. One explanation is that the oral health professionals visited did not concern to aware the family unit about this issue. In other studies, when the mothers were asked from whom they had received information about the children's oral health care, only $10 \%$ of them had received information from dentists. ${ }^{11,12}$ The main sources of information were family members and other mothers. ${ }^{12}$ Since the dentist is responsible to provide oral health care, the need to make population aware of oral health-related issues, with strategies targeted at individual, family and community levels should also be taken into account.

On the other way, efforts from the oral health professionals to make people aware about oral health related issues may not be enough as a predictor of good OHK and OHP. In this study, although more than a half of mothers had received information about children's oral health during prenatal care, their OHK and OHP was still shown to be poor. And this result corroborates with Heaton et al. ${ }^{22}$ whose findings had shown that knowledge itself may not be enough to promote positive oral health behaviors. Despite pregnancy ${ }^{26}$ and puerperal ${ }^{27}$ are effective periods to make mothers aware regarding their babies' oral health, the reinforcement of these pieces of information should be considered in every child's dental appointment. Also, the factors that may have an influence on OHK and OHP should be concerned to plan and conduct interventions in order to prevent and promote children's oral health in a comprehensive and effective way to the target audience. It would also be important that the recommendations were unified among all the health professionals that provide health care to mother and child units. ${ }^{28}$

The limitations of this study include the lack of evaluation of babies' oral health in the third stage of data collection, or in a further new stage in the study. This would enable the assessment of an association between mothers' OHP and children's oral health. Another limitation is the lack of evaluation of mothers' oral health, in order to verify its association with children's oral health status, which is reported in a previous study. ${ }^{29}$ In addition, this study was carried out with children that were born in a single hospital, so that the generalization of the results should be cautious.

\section{Conclusion}

The findings of this study highlighted the social determination of mothers' oral health-related knowledge, as it was influenced by the mother's age, education level and social class. They also highlighted the need of an improvement of mothers' oral health-related knowledge and practices. Educational actions, especially in prenatal programs, are important to achieve this improvement and to decrease early childhood caries rates. In addition, these strategies would contribute to reduce the risk of chronic diseases, as obesity, since they have etiologic factors in common with early childhood caries.

\section{Acknowledgements}

The authors would like to acknowledge the students from the Post-Graduate Program in Nursing, from the State University of Londrina, for the support with the data collection.

\section{References}

1. Chaffee BW, Feldens CA, Rodrigues PH, Vítolo MR. Feeding practices in infancy associated with caries incidence in early childhood. Community Dent Oral Epidemiol 2015;43(4):33848. doi: https://doi.org/10.1111/cdoe.12158

2. Dos Santos Junior VE, de Sousa RMB, Oliveira MC, de Caldas Junior AF, Rosenblatt A. Early childhood caries and its relationship with perinatal, socioeconomic and nutritional risks: A cross-sectional study. BMC Oral Health 2014; 14(1):15. doi: https://doi.org/10.1186/1472-6831-14-47

3. Khanh LN, Ivey SL, Sokal-gutierrez K, Barkan H, Ngo KM. Early Childhood Caries, Mouth Pain, and Nutritional Threats in Vietnam. Am J Public Health 2015;105(12):2510-18. doi: https://doi.org/10.2105/AJPH.2015.302798

4. Martins-Júnior PA, Vieira-Andrade RG, Corrêa-Faria P, Oliveira-Ferreira F, Marques LS, Ramos-Jorge ML. Impact of early childhood caries on the oral health-related quality of life of preschool children and their parents. Caries Res 2013;47(3):211-8. doi: https://doi.org/10.1159/000345534

5. Ribeiro CCC, Da Silva MCB, Nunes AMM, Thomaz ÉBAF, Carmo CDS, Ribeiro MRC, et al. Overweight, obese, underweight, and frequency of sugar consumption as risk indicators for early childhood caries in Brazilian preschool children. Int J Paediatr Dent 2017;27(6):532-9. doi: https:// doi.org/10.1111/ipd.12292

6. Consolação Soares ME, Ramos-Jorge ML, de Alencar BM, Marques LS, Pereira LJ, Ramos-Jorge J. Factors associated with masticatory performance among preschool children. Clin Oral Investig 2017;21(1):159-66. doi: https://doi. org/10.1007/s00784-016-1768-5

7. Hallas D, Fernandez JB, Lim LJ, Catapano P, Dickson SK, Blouin KR, et al. OHEP: An Oral Health Education Program for Mothers of Newborns. J Pediatr Heal Care 2015;29(2):18190. doi: https://doi.org/10.1016/j.pedhc.2014.11.004

8. Saied-Moallemi Z, Virtanen JI, Ghofranipour F, Murtomaa $H$. Influence of mothers' oral health knowledge and attitudes on their children's dental health. Eur Arch Paediatr Dent 2008;9(2):79-83. doi: https://doi.org/10.1007/BF03262614

9. Tyagi U, Menon I, Tomar D, Singh A, Goyal J. Association between maternal oral health literacy and their preschoolers' oral health outcomes in Muradnagar -A cross-sectional study. J Dent Spec 2017;5(2):98-102. doi: https://doi. org/10.18231/2393-9834.2017.0024

10. Dhull KS, Dutta B, Devraj IM, Samir P V. Knowledge , Attitude, and Practice of Mothers towards Infant Oral Healthcare. Int J Clin Pediatr Dent 2018;11(5):435-9. doi: https://doi.org/10.5005/jp-journals-10005-1553

11. Shetty R, Deoghare A, Rath S, Sarda R, Tamrakar A. Influence of mother's oral health care knowledge on oral health status of their preschool child. Saudi J Oral Sci 2016;3(1):12. doi: https://doi.org/10.4103/1658-6816.174291

12. Chala S, Houzmali S, Abouqal R, Abdallaoui F. Knowledge, attitudes and self-reported practices toward children oral 
health among mother's attending maternal and child's units, Salé, Morocco. BMC Public Health 2018;18(1):2-9. doi: https://doi.org/10.1186/s12889-018-5542-2

13. McGowan L, Cooke LJ, Gardner B, Beeken RJ, Croker $\mathrm{H}$, Wardle J. Healthy feeding habits: efficacy results from a cluster-randomized, controlled exploratory trial of a novel, habit-based intervention with parents. Am J Clin Nutr 2013;98(3):769-77. doi: https://doi.org/10.3945/ ajen.112.052159

14. Kelly MP. How to make the first thousand days count. Heal Promot J Aust 2018;29(S1):17-21. doi: https://doi. org/10.1002/hpja.58

15. Koletzko B, Brands B, Chourdakis M, Cramer S, Grote $\mathrm{V}$, Hellmuth $\mathrm{C}$, et al. The power of programming and the earlynutrition project: Opportunities for health promotion by nutrition during the first thousand days of life and beyond. Ann Nutr Metab 2014;64(3/4):187-96. doi: https://doi.org/

16. Pentecost M, Ross F. The First Thousand Days: Motherhood, Scientific Knowledge, and Local Histories. Med Anthropol Cross Cult Stud Heal Illn. 2019;38(8):747-61. doi: https:// doi.org/10.1159/000365017

17. Chi DL, Luu M, Chu F. A scoping review of epidemiologic risk factors for pediatric obesity: Implications for future childhood obesity and dental caries prevention research. J Public Health Dent 2017;77(2):8-31. doi: https:/doi. org/10.1111/jphd.12221

18. Thomas A, Jacob A, Kunhambu D, Shetty P, Shetty S. Evaluation of the knowledge and attitude of expectant mothers about infant oral health and their oral hygiene practices. J Int Soc Prev Community Dent 2015;5(5):400. doi: https://doi. org/10.4103/2231-0762.163405

19. American Dental Association. Statement on Early Childhood Caries. 2000;1-4.

20. Avasare T, Warren J, Qian F, Marshall T, Weber-Gasparoni $\mathrm{K}$, Drake D. Longitudinal study assessing factors associated with mutans streptococci acquisition in Infants and Toddlers. Oral Heal Prev Dent 2018;15(6):543-8. doi: https://doi. org/10.3290/j.ohpd.a39226

21. Foterek K, Buyken AE, Bolzenius K, Hilbig A, Nöthlings U, Alexy U. Commercial complementary food consumption is prospectively associated with added sugar intake in childhood. Br J Nutr 2016;115(11):2067-74. doi: https://doi. org/10.1017/S0007114516001367

22. Heaton B, Crawford A, Garcia RI, Henshaw M, Riedy CA, Barker JC, et al. Oral health beliefs, knowledge, and behaviors in Northern California American Indian and Alaska Native mothers regarding early childhood caries. J Public Health Dent 2017;77(4):350-9. doi: https://doi.org/10.1111/ jphd.12217

23. Tham R, Bowatte G, Dharmage S, Tan D, Lau M, Dai X, et al. Breastfeeding and the risk of dental caries: A systematic review and meta-analysis. Acta Paediatr 2015;104:62-84. doi: https://doi.org/10.1111/apa.13118

24. Feldens CA, Fortuna MJ, Kramer PF, Ardenghi TM, Vítolo MR, Chaffee BW. Family Health Strategy associated with increased dental visitation among preschool children in Brazil. Int J Paediatr Dent 2018;28(6):624-32. doi: https:// doi.org/10.1111/ipd.12421

25. Secretaria de Estado da Saúde do Paraná. Linha guia - Rede mãe paranaense. 2018. Available from: http://www.saude. pr.gov.br/arquivos/File/LinhaGuiaMaeParanaense_2018.pdf

26. Ramazani N, Zareban I, Ahmadi R, ZadSirjan S, Daryaeian M. Effect of Anticipatory Guidance Presentation Methods on the Knowledge and Attitude of Pregnant Women Relative to Maternal, Infant and Toddler's Oral Health Care. J Dent (Tehran) 2014;11(1):22-30.

27. Yuan S. Evaluating an oral health education intervention in Chinese undocumented migrant mothers of infants in Northern Ireland. Dent J 2019;7(1):1-13. doi: https://doi. org/10.3390/dj7010008

28. Wagner Y, Heinrich-Weltzien R. Midwives' oral health recommendations for pregnant women, infants and young children: Results of a nationwide survey in Germany. BMC Oral Health 2016;16(1):1-9. doi: https://doi.org/10.1186/ s12903-016-0192-1

29. Olak J, Nguyen MS, Nguyen TT, Nguyen BBT, Saag M. The influence of mothers' oral health behaviour and perception thereof on the dental health of their children. EPMA J 2018;9(2):187-93. doi: https://doi.org/10.1007/s13167-0180134-X 